\title{
Kinetic and Isotherm Modelling of the Adsorption of Phenolic Compounds from Olive Mill Wastewater onto Activated Carbon
}

\author{
Bahar Aliakbarian*, Alessandro A. Casazza and Patrizia Perego \\ Department of Civil, Chemical and Environmental Engineering, University of Genoa, \\ Via Opera Pia 15, IT-16145 Genoa, Italy
}

Received: July 2, 2014

Accepted: January 27, 2015

\begin{abstract}
Summary
The adsorption of phenolic compounds from olive oil wastewater by commercial activated carbon was studied as a function of adsorbent quantity and temperature. The sorption kinetics and the equilibrium isotherms were evaluated. Under optimum conditions (8 $\mathrm{g}$ of activated carbon per $100 \mathrm{~mL}$ ), the maximum sorption capacity of activated carbon expressed as $\mathrm{mg}$ of caffeic acid equivalent per $\mathrm{g}$ of activated carbon was 35.8 at $10^{\circ} \mathrm{C}, 35.4$ at $25^{\circ} \mathrm{C}$ and 36.1 at $40^{\circ} \mathrm{C}$. The pseudo-second-order model was considered as the most suitable for kinetic results, and Langmuir isotherm was chosen to better describe the sorption system. The results confirmed the efficiency of activated carbon to remove almost all phenolic compound fractions from olive mill effluent. The preliminary results obtained will be used in future studies. The carbohydrate fraction of this upgraded residue could be employed to produce bioethanol, and adsorbed phenolic compounds can be recovered and used in different industries.
\end{abstract}

Key words: olive wastewater treatment, kinetics, polyphenol adsorption, activated carbon, modelling

\section{Introduction}

The olive oil industries generate huge amounts of wastes with great environmental impact (1). Olive oil wastewater, as one of the main olive oil extraction residues is an acidic liquid ( $\mathrm{pH}=5-5.5)$ that contains traces of olive pulp, pectins and oil. Moreover, the presence of organic substances, particularly polyphenols, has been reported to be associated with the negative effects of this waste on soil, aquatic and air ecosystems (2). Large amount of phenolic compounds, free fatty acids and inorganic salts are known as the major causes of the high phytotoxicity and poor biodegradability of olive mill wastewater (3). As a consequence, increasing attention has been given to finding suitable methods for the control of this pollutant. Several works have concentrated on this problem taking approaches such as treatment with calcium hydroxide or fermentation with microorganisms, or even co-composting with olive stone wooden residue (4). All of these methods lead to degradation of phenolic compounds in this effluent in an irreversible and nonrecoverable manner.

On the other hand, the importance of polyphenols as bioactive compounds with many interesting activities has been widely discussed in the past years (5). Phenolic compounds act as antioxidants (6-9), neurosedative, anti-inflammatory, antiviral and anticancer agents (10). It has been indicated that verbascoside and its analogues from olive fruit can consistently contribute to the intake of antioxidants in the diet (11). Therefore, an appropriate application of olive oil residues could not only improve the economic status of olive oil producers but could also reduce such an environmental problem. Thus, the possibili- 
ty of recovering an extract enriched with phenolic compounds, obtained from a low-cost and widely available by-product, is of great interest especially in the Mediterranean area.

Recently, a large amount of literature has been increasingly devoted to the study of adsorption for the removal of aqueous organic species, such as substituted and unsubstituted phenols using activated carbon (AC) (12-14). AC has perfect adsorption ability for relatively low molecular mass organic compounds, such as phenols. Adsorption onto AC is the physical and/or chemical process in which a substance is accumulated at an interface between two phases. Removal by AC is obtained as a result of attractive interaction of the molecules with the walls of micro- or mesopores with dimensions comparable to those of the molecules (15). AC has been utilised as an efficient sorbent for odour removal, solvent recovery, decolourisation, dechlorination, ozone annihilation, $\mathrm{H}_{2} \mathrm{~S}$ / $\mathrm{CS}_{2}$ removal, gold recovery, filtration, fuel gas cleaning, industrial wastewater treatment, drinking water conditioning, etc. (16). Although several papers about the adsorption of phenolic compounds from aqueous media on AC have been reported, there are few publications that discuss the characteristics of adsorption from multicomponent solutions. The importance of polyphenols as bioactive compounds encouraged us to recover polyphenols from wastewater by the adsorption onto activated carbon, because the process of regenerating the adsorbent by desorption of the organic compounds poses an important problem for the current studies since they have high affinity towards the sorbent surface. Several techniques such as chemical (17), thermal (18) degradation and ultrasound (19) have been used for the desorption of phenols from AC. $\mathrm{NaOH}$ solution proved to be efficient in recovering the adsorbed phenolics from AC by formation of sodium salt of phenols, which may facilitate desorption. Özkaya (14) and, more recently, Ena et al. (20) reported that $0.15 \mathrm{M}$ $\mathrm{NaOH}$ is required for quantitative desorption of phenols from AC. The desorbed phenolic fraction was more than $60 \%$ when using $0.15 \mathrm{M} \mathrm{NaOH}$ eluent. Different factors affect adsorption capacity such as the physical nature of the pore structure of the adsorbent, functional groups, the nature of the adsorbate, molecular mass, size and solution conditions ( $\mathrm{pH}$ and ionic strength). Changes in surface charges with $\mathrm{pH}$ can affect the reversible and irreversible uptakes of phenolics. This may be due to the increase in activity of phenolic compounds with decreasing $\mathrm{pH}$ and this influence on reversible uptake should be minimal at compound $\mathrm{pH}$ values well below the solute $\mathrm{p} K_{\mathrm{a}}$. It can be concluded from the dependence of the irreversible adsorption that oxidative coupling of phenolic compounds is more facile in alkaline than in acidic media (21).

The aim of this work is to study the adsorption capacity of a cost-effective and environmentally compatible adsorbent for the removal of phenolic compounds present in olive mill wastewater. In this study commercial activated carbon was used. The effect of some operating conditions, such as adsorbent quantity ( 1 to $8 \mathrm{~g}$ per $100 \mathrm{~mL}$ ) and temperature $\left(10,25\right.$ and $\left.40^{\circ} \mathrm{C}\right)$, were investigated. The kinetic data were fitted with pseudo-first and -second order kinetic models. The Langmuir and Freundlich models were used to describe the equilibrium isotherms. The results obtained from the present study will be used in further research of recovery of adsorbed phenolic compounds. After purification processes, these valuable compounds can be used in food, cosmetic and pharmaceutical industries.

\section{Material and Methods}

\section{Reagents}

Methanol, acetonitrile, sulphuric acid, acetic acid (HPLC grade), Folin-Ciocalteu reagent and caffeic acid standard were purchased from Sigma-Aldrich Chemical Co (St. Louis, MO, USA). Glucose and fructose standards were obtained from Merck KGaA (Darmstadt, Germany). Standard stock solutions were prepared, wrapped in aluminium foil and stored at $-20^{\circ} \mathrm{C}$.

The commercial activated carbon (AC; Sigma-Aldrich Chemical Co) was used in the batch experiments without any pretreatment. The cost of commercial AC can vary from $\$ 800$ to 2000 per metric tonne depending on the quality of the product. The AC used in this study has the pore size of $2.98 \mathrm{~nm}$, specific surface area (Brunnauer, Emmett and Teller (BET) theory) $920.3 \mathrm{~m}^{2} / \mathrm{g}$, maximum moisture $2.0 \%$, iodine number 800 , bulk density 0.336 $\mathrm{kg} / \mathrm{L}, \mathrm{pH}=9$ in water extract, ash $6 \%$, methylen blue adsorption of $12.5 \mathrm{~g}$ per $100 \mathrm{~g}$ per min and molasses decolourising number 440. Powder X-ray diffraction (XRD; Philips PW 1830 generator, Eindhoven, the Netherlands) and Fourier transform infrared spectroscopy (FTIR) were used, and the sample patterns are illustrated in Fig. 1. For FTIR analysis the matrices were dispersed on a pressed disk of $\mathrm{KBr}$ and analysed by a FTIR spectrometer (Nicolet 380, Thermo Scientific, Waltham, MA, USA), the spec-
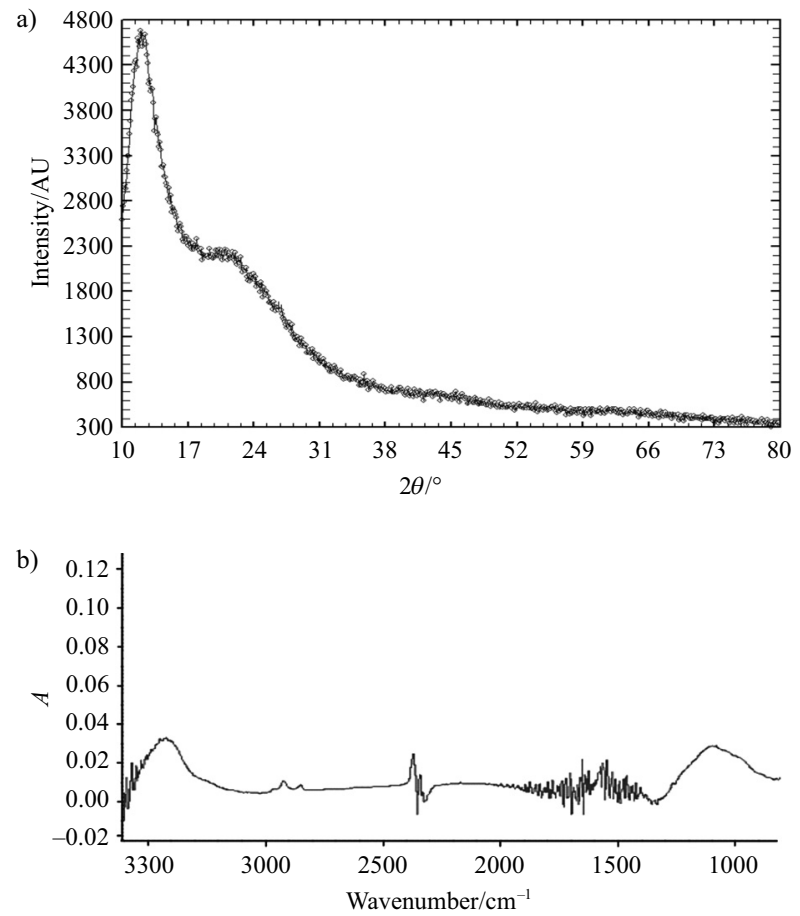

Fig. 1. The patterns of commercial activated carbon: a) XRD and b) FTIR spectra 
trum was analysed using the Omnic ${ }^{\mathrm{TM}}$ Lite software (Thermo Electron Corporation, Madison, WA, USA). X-ray pattern (Fig. 1a) shows the amorphous form of the used sample. Fig. $1 \mathrm{~b}$ indicates the functional groups and surface properties of the adsorbent determined by FTIR spectra. The spectra of the adsorbent were measured in the wavenumber range of $4000-400 \mathrm{~cm}^{-1}$. The most intense peak at $3425 \mathrm{~cm}^{-1}$ can be assigned to alcohol or phenol -OH stretching. Peaks at 1968 and $2850 \mathrm{~cm}^{-1}$ are attributed to symmetric and asymmetric $\mathrm{CH}_{2}$ stretching, respectively. The peak around $1081 \mathrm{~cm}^{-1}$ shows the appearance of $\mathrm{C}-\mathrm{O}$ stretching on the carbon surface.

\section{Olive oil wastewater and characteristics}

Olive mill wastewater from the treatment of Taggiasca cultivar obtained from three-phase oil extraction decanter was supplied by an olive oil production plant in Imperia, Liguria region (Italy). Adequate quantities of samples were centrifuged by a PK 131 centrifuge (ALC, Alberta, Canada) at $6000 \times g$ for $10 \mathrm{~min}$ in order to separate suspended solids.

The value of chemical oxygen demand (COD) was estimated using the method described by Knechtel (22). Simple carbohydrates such as glucose and fructose were determined directly by high-performance liquid chromatography (1100 Series, Hewlett Packard, Palo Alto, CA, USA) as reported by Garrote et al. (23), using a refractive index detector and a Supelcogel H59304-U column (Sigma-Aldrich Corp., Bellefonte, PA, USA). Samples were filtered through 0.45- $\mu \mathrm{m}$ membranes (Millipore, Billerica, MA, USA). Separation was achieved using $0.005 \mathrm{M} \mathrm{H}_{2} \mathrm{SO}_{4}$ as mobile phase at a flow rate of $0.5 \mathrm{~mL} / \mathrm{min}$ at $50{ }^{\circ} \mathrm{C}$.

Total polyphenol (TP) concentration was measured using the Folin-Ciocalteu assay $(24,25)$. Briefly, $4.8 \mathrm{~mL}$ of pure water, $0.2 \mathrm{~mL}$ of sample, and $0.5 \mathrm{~mL}$ of Folin-Ciocalteu reagent were mixed and $1 \mathrm{~mL}$ of a $20 \%$ sodium carbonate solution was added. Pure water was added to reach the final volume of $10 \mathrm{~mL}$. Solutions were mixed and allowed to stand at room temperature in the dark for $1 \mathrm{~h}$. Sample aliquots were used for the determination of total phenolic concentration using an UV-VIS spectrophotometer (Perkin Elmer, Wellesley, MA, USA) at a wavelength of $725 \mathrm{~nm}$. TP was standardised against caffeic acid and expressed as mg of caffeic acid equivalents (CAE) per $\mathrm{mL}$ of wastewater. The method response was described with the following linear equation within the range of $0.1-1.0 \mathrm{mg} / \mathrm{mL}$ with $\mathrm{R}^{2}=0.9962$.

$$
A_{725 \mathrm{~nm}}=0.002 \cdot \mathrm{TP}-0.004
$$

The concentration of $o$-diphenols (OD) in the methanolic extract, also expressed as CAE in $\mathrm{mg} / \mathrm{mL}$, was determined by the molybdate method (26): $0.2 \mathrm{~mL}$ of extract was diluted with water to reach $1.0 \mathrm{~mL}$, and then $1.0 \mathrm{~mL}$ of $0.1 \mathrm{M}$ phosphate buffer $(\mathrm{pH}=6.5)$ and $2.0 \mathrm{~mL}$ of $5 \%$ $\mathrm{Na}_{2} \mathrm{MoO}_{4} \cdot 2 \mathrm{H}_{2} \mathrm{O}$ were added. The content was mixed and the absorbance was measured after $15 \mathrm{~min}$ at $350 \mathrm{~nm}$ against a blank reagent using the same spectrophotometer as above. The calibration curve was made with standard solutions of caffeic acid in the range of $0.01-0.25 \mathrm{mg} /$ $\mathrm{mL}$, giving the following equation:

$$
A_{350 \mathrm{~nm}}=0.004 \cdot \mathrm{OD}+0.001
$$

\section{Adsorption experiments}

In order to simplify the adsorption process, batch experiments were carried out in 100-mL Erlenmeyer flasks containing $(25 \pm 0.2) \mathrm{mL}$ of centrifuged wastewater and different quantities of adsorbent $(0.25,0.5,1,1.5$ and $2 \mathrm{~g})$. The flasks were placed at 10,25 and $40{ }^{\circ} \mathrm{C}$, using a thermo-regulated water bath, model SWB25 (Enco, Spinea, Venice, Italy) in order to study the influence of temperature on sorption. When the desired temperature was reached, a known amount of adsorbents was added to each flask and the solutions were agitated on a rotary shaker at 200 $\mathrm{rpm}$. At predefined time intervals $(10,20,30,40,50,60,80$, 100 and $120 \mathrm{~min})$, a constant quantity of sample $(1.0 \mathrm{~mL})$ was taken. The adsorbent was separated from the samples using membrane filters of $0.2 \mu \mathrm{m}$ (Millipore). Residual concentration of total polyphenols in each sample was determined using Folin-Ciocalteu method as described above. All experiments were conducted in duplicate, and the error was always less than $6 \%$, calculated by dividing standard deviation by average of different quantities of polyphenols and expressed as percentage. Each adsorption experiment was conducted in duplicate while total polyphenol concentration analyses were determined in triplicates.

\section{Sorption kinetics and isotherms}

Adsorption kinetics was evaluated by applying the Lagergren model (27) and the pseudo-second-order equation of Ho and McKay (28). The linearized form of the model of Lagergren gave the following equation:

$$
\log \left(q_{\mathrm{e}}-q\right)=\log q_{\mathrm{e}}-\frac{k_{1}}{2.303} t
$$

where $q$ is the amount of TP (expressed as CAE in $\mathrm{mg}$ ) adsorbed per $\mathrm{g}$ of adsorbent at a given time $(t)$ and was used in plots of $\log \left(q_{\mathrm{e}}-q\right) v s$. time to estimate the first-order-rate constant of sorption, $k_{1}\left(\mathrm{~min}^{-1}\right)$.

The capability of activated carbon as sorbent was evaluated in terms of sorption capacity at equilibrium $\left(q_{\mathrm{e}}\right)$, expressed in $\mathrm{g}$ of CAE per $\mathrm{g}$ of activated carbon:

$$
q_{\mathrm{e}}=\left(\gamma_{0}-\gamma_{\mathrm{e}}\right) \cdot \frac{V}{m}
$$

where $\gamma_{0}$ and $\gamma_{\mathrm{e}}$ are the initial and equilibrium liquid-phase phenol concentrations (expressed as mg of CAE per L), respectively, $V$ is the volume of the wastewater $(\mathrm{mL})$ and $m$ is the mass of activated carbon used $(\mathrm{g})$. The efficiency of the removal of phenolics $\left(Y_{\mathrm{e}}\right)$ was expressed in percentage:

$$
Y_{\mathrm{e}}=\left(\frac{\gamma_{0}-\gamma_{\mathrm{e}}}{\gamma_{0}}\right) \cdot 100
$$

The pseudo-second-order model (29), based on the sorption capacity of the solid phase and consistent with the chemisorptions mechanism, is described by the following equation:

$$
\frac{t}{q}=\frac{1}{k_{2} \cdot q_{\mathrm{e}}^{2}}+\frac{t}{q_{\mathrm{e}}}
$$

Plots of $t / q$ vs. time at different activated carbon quantities were used to estimate the second-order-rate constant of sorption, $k_{2}$ (g of AC per mg of CAE per min). 
Several models have been published in the literature that describe experimental data of adsorption isotherm (14-16). The Langmuir (29) and Freundlich models (30) are simple and most frequently applied. The Langmuir isotherm is based on the assumption of monolayer adsorption onto a surface containing finite number of adsorption sites of uniform energies of adsorption with no transmigration of adsorbate in the pores of the adsorbent surface. The linearized form of the Langmuir isotherm model (Eq. 7) was used to determine equilibrium data:

$$
\frac{\gamma_{\mathrm{e}}}{q_{\mathrm{e}}}=\frac{1}{K_{\mathrm{L}} \cdot q_{\mathrm{m}}}+\frac{\gamma_{\mathrm{e}}}{q_{\mathrm{m}}}
$$

where $q_{\mathrm{m}}$ is the maximum sorption capacity (mg of CAE per $g$ of $\mathrm{AC}$ ) and $K_{\mathrm{L}}$ is the Langmuir equilibrium constant (mL per mg of CAE).

The Freundlich model (Eq. 8) assumes heterogeneous surface energies, where adsorption energy varies as a function of the surface coverage due to variation in the adsorption heat (16).

$$
\ln q_{\mathrm{e}}=\ln K_{\mathrm{F}}+\frac{1}{n} \ln \gamma_{\mathrm{e}}
$$

in which $K_{\mathrm{F}}(\mathrm{mg}$ of CAE per $\mathrm{g}$ of $\mathrm{AC})(\mathrm{mg} \text { of CAE per } \mathrm{L})^{\mathrm{n}}$ and $n$ (dimensionless) are constants for a given sorbate and sorbent, respectively, at a particular temperature, which are related to the sorption capacity and intensity, respectively.

For better understanding of the mechanism of adsorption of phenolics on activated carbon, in this work the experimental data of the adsorption of phenolics were fitted and compared with the well-known Freundlich and Langmuir models and the goodness of fit was evaluated. The Freundlich model is widely applied (31-33) in heterogeneous systems especially of organic compounds and highly interactive species on activated carbon and molecular sieves. The parameters and constants appearing in both equations were estimated by linear regression, by plotting $\gamma_{\mathrm{e}} / q_{\mathrm{e}} v s . \gamma_{\mathrm{e}}$ in the former case and $\ln q_{\mathrm{e}} v s . \ln \gamma_{\mathrm{e}}$ in the latter.

\section{Results and Discussion}

\section{Effect of adsorbent quantity and temperature}

The physicochemical characteristics of olive oil wastewater are represented in Table 1.

Table 1 . The physicochemical characteristics of olive mill wastewater from Taggiasca cultivar treatment

\begin{tabular}{lc}
\hline Content & Value \\
\hline $\mathrm{pH}$ & 4.9 \\
$\rho /\left(\mathrm{g} / \mathrm{cm}^{3}\right)$ & 1.0 \\
$\mathrm{COD} /(\mathrm{g} / \mathrm{L})$ & 65.0 \\
$\gamma($ total polyphenols $) /(\mathrm{mg} / \mathrm{mL})$ & 3.0 \\
$\gamma($ total $o$-diphenols $) /(\mathrm{mg} / \mathrm{mL})$ & 1.2 \\
$\gamma($ glucose $) /(\mathrm{g} / \mathrm{L})$ & 3.1 \\
$\gamma($ fructose $) /(\mathrm{g} / \mathrm{L})$ & 6.4 \\
\hline
\end{tabular}

Total polyphenols and $o$-diphenols are expressed as caffeic acid equivalents. $\mathrm{COD}=$ chemical oxygen demand
The concentration of the used AC is an important factor that controls adsorption (34). It is well known that temperature is an additional factor that greatly influences any sorption process. Therefore, tests were performed at three different temperatures, room temperature $\left(25^{\circ} \mathrm{C}\right)$, above $\left(40{ }^{\circ} \mathrm{C}\right)$ and bellow $\left(10^{\circ} \mathrm{C}\right)$ it. In order to observe the simultaneous effect of the temperature and adsorbent quantity on the adsorption of polyphenols, adsorbent concentration was varied from 1 to 8 g per $100 \mathrm{~mL}$. Different tests were performed using the same quantity of wastewater $(25 \mathrm{~mL})$ and constant phenolic concentration $(3.0 \mathrm{mg} / \mathrm{mL})$, but varying the quantity of activated carbon $(0.25,0.5,1.0,1.5$ and $2.0 \mathrm{~g})$. Adsorption trends at different temperatures can be observed in Figs. 2 and 3.
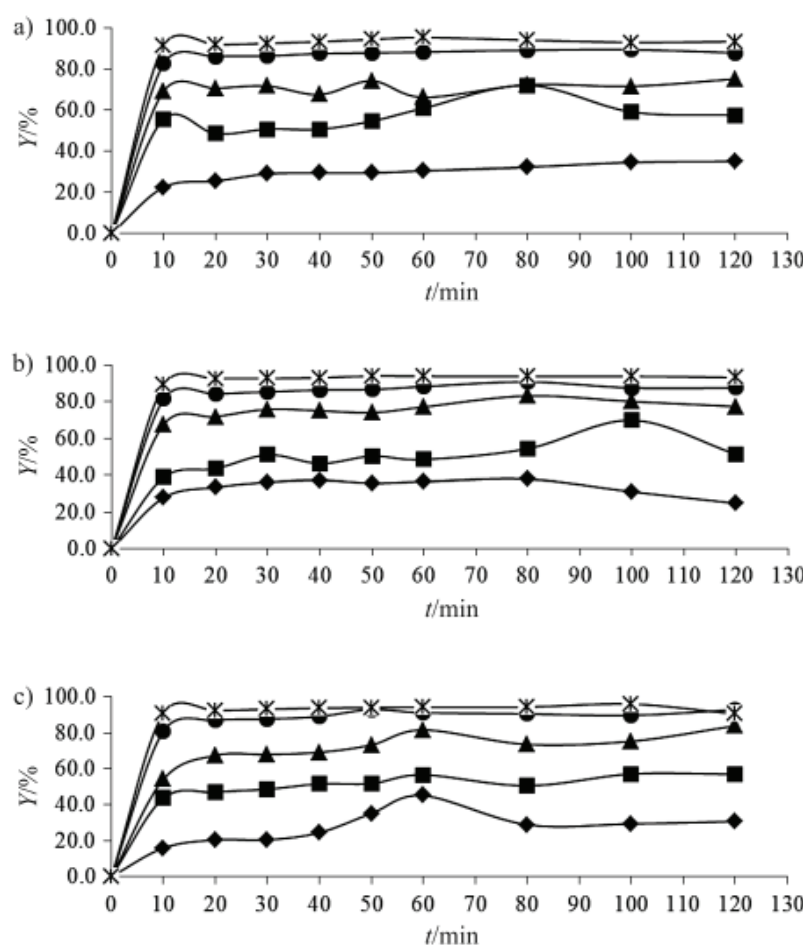

Fig. 2. Effect of different activated carbon concentrations (in $\mathrm{g}$ per $100 \mathrm{~mL}$ ): $1.0, \boldsymbol{2} .0, \boldsymbol{\Delta} 4.0, \bullet 6.0$ and $* 8.0$ on total polyphenol removal efficiency $\left(Y\right.$ at: a) $10^{\circ} \mathrm{C}$, b) $25^{\circ} \mathrm{C}$ and c) $40^{\circ} \mathrm{C}$

As illustrated in Fig. 3, the initial velocities and adsorption percentage $(Y)$ enhanced as the amount of actived carbon increased. This can be explained by the presence of multiple sites available initially.

At each measured temperature, adsorption capacity $\left(q_{\mathrm{e}}\right)$ decreased with the increase of the AC concentration. At higher concentration of activated carbon ( $8 \mathrm{~g}$ per 100 $\mathrm{mL}$ ), the saturation of surface-active sites with the adsorbate molecules causes no more significant adsorption (34). These findings are in accordance with those obtained by Qadeer and Rehan (17), who observed that increasing the concentration of commercial activated carbon from 0.02 to $0.14 \mathrm{~g}$ per $10 \mathrm{~mL}$ of wastewater with initial phenolic concentration of $0.01 \mathrm{~g} / \mathrm{L}$ resulted in $5 \%$ increase in the adsorption of phenols. Moreover, Özkaya (14) demonstrated that increasing $\mathrm{AC}$ concentration from 0.5 to $9.0 \mathrm{~g} / \mathrm{L}$ re- 

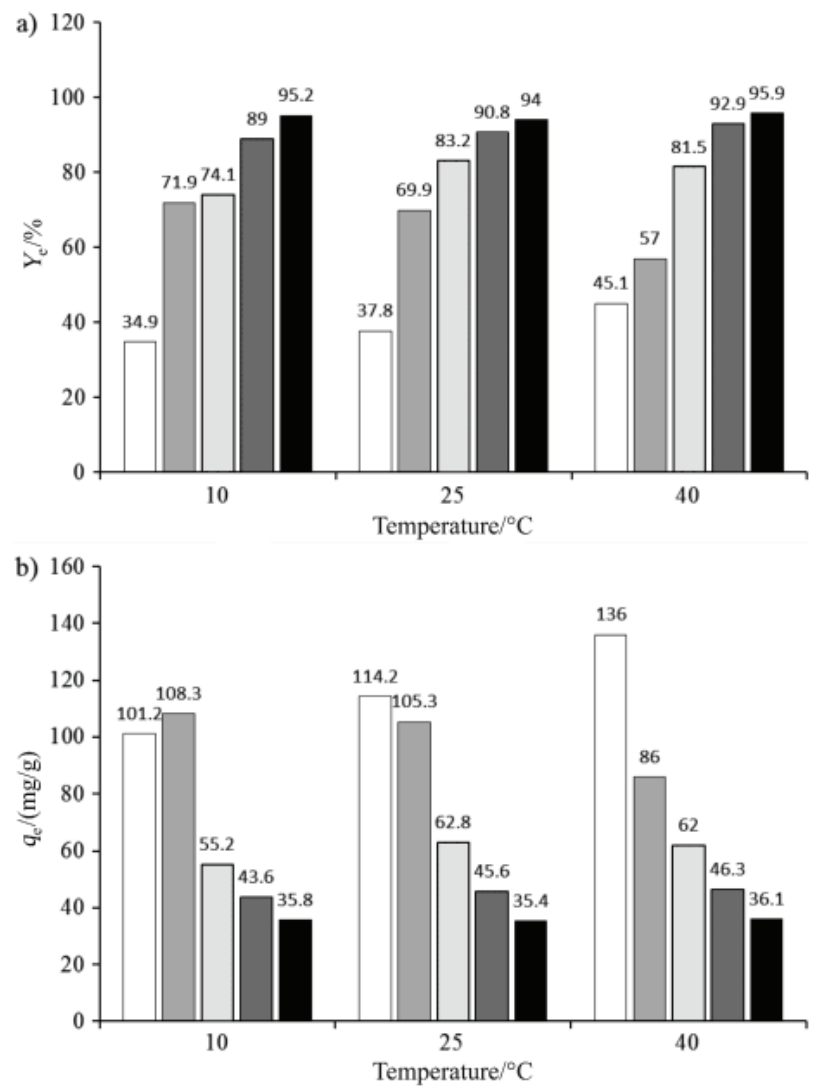

Fig. 3. Capability of activated carbon (AC) as sorbent in terms of: a) removal efficiency $\left(Y_{\mathrm{e}}\right)$, or b) sorption capacity $\left(q_{\mathrm{e}}\right)$ at equilibrium of phenolic compounds (expressed as CAE in mg per $g$ of $\mathrm{AC}$ ) from olive mill wastewater from Taggiasca cultivar treatment at different temperatures and adsorbent concentrations (in g per $100 \mathrm{~mL}$ ): $\square 1.0, \square 2.0, \square 4.0, \square 6.0$ and $\square$ 8.0. CAE=caffeic acid equivalents

sulted in the increase of the efficiency of removal of phenols from 45 to $96 \%$ after $2 \mathrm{~h}$ of contact time and initial concentration of phenols of $100 \mathrm{~g} / \mathrm{L}$.

Significant changes were not observed at different applied temperatures at the AC concentration of $8 \mathrm{~g}$ per $100 \mathrm{~mL}$, for example adsorption capacity was 35.8, 35.4 and $36.1 \mathrm{mg} / \mathrm{g}$ at 10,25 and $40{ }^{\circ} \mathrm{C}$, respectively. Zogorski and Faust (35) reported that adsorptive capacity of phenols on granular activated carbon was increased with the decrease of temperature.

It can be observed in the literature that $\mathrm{H}_{3} \mathrm{PO}_{4}(36)$, sewage sludge (37), fly ash (38) and activated carbon from agricultural by-products (39) used in the petroleum coke treatment can be adsorbents of phenolic compounds with high adsorbent capacities (158, 94, 67 and $35.0 \mathrm{mg} / \mathrm{g}$ ).

\section{Adsorption equilibrium modelling}

The Freundlich and Langmuir models were applied to the equilibrium data obtained for total polyphenol adsorption on AC. Table 2 describes the adsorption constants for both models obtained from the isotherms, and the linear regression coefficient for each evaluated condition.

According to the Langmuir model, the maximum values of adsorption capacity of AC were 126.6, 156.2 and $151.5 \mathrm{mg} / \mathrm{g}$ at 10,25 and $40{ }^{\circ} \mathrm{C}$. The adsorption increased with the increase in temperature from 10 to $25^{\circ} \mathrm{C}$, reflecting the endothermic nature of the reaction, until equilibrium was obtained and then it decreased. The use of endothermic processes for the adsorption of organic compounds on activated carbon has been reported previousely $(16,40$, 41). An increase in temperature from 25 to $40{ }^{\circ} \mathrm{C}$ caused a decrease in the amount of phenols adsorbed onto the surface of the adsorbent. At high temperature, the thickness of the boundary layer is expected to decrease due to the increased tendency of the phenolic compounds to escape from the surface of the adsorbent to the solution phase (due to the increase in kinetic energy of the ions), hence there are weak adsorption interactions between the adsorbent and the adsorbate (42). The Langmuir equilibrium constant $\left(K_{\mathrm{L}}\right)$, which is related to the affinity between phenolics and sorbent, was lower at $25{ }^{\circ} \mathrm{C}(1.60 \mathrm{~mL} / \mathrm{mg})$ when compared to the other temperatures, indicating a better affinity between the AC and these compounds.

From the data reported in Table 3, it can be observed that the Langmuir model fitted better the equilibrium data at temperatures lower than $40{ }^{\circ} \mathrm{C}\left(\mathrm{R}^{2}=0.9401\right.$ at $10^{\circ} \mathrm{C}$ and 0.9709 at $25^{\circ} \mathrm{C}$ ) when compared with Freundlich model $\left(\mathrm{R}^{2}=0.7667\right.$ at $10^{\circ} \mathrm{C}$ and 0.9511 at $\left.25^{\circ} \mathrm{C}\right)$, thus confirming the poor applicability of Freundlich isotherm for this type of sorption process. On the other hand, at $40^{\circ} \mathrm{C}$, the Freundlich isotherm seems to explain better the experimental data $\left(R^{2}=0.9310\right.$ compared to 0.9194 in the case of Langmuir model). Qadeer and Rehan (17) as well as Özkaya (14) also confirmed better fitting of experimental data for adsoption of phenolic compounds onto activated carbon by Langmuir model than by the Freundlich model.

\section{Adsorption kinetics modelling}

The kinetics of the adsorption of phenolic compounds onto AC was investigated in order to understand the mech-

Table 2. Isotherm parameters of Langmuir and Freundlich models of the sorption of phenolic compounds (expressed as mg of CAE per $\mathrm{g}$ of $\mathrm{AC}$ ) from olive mill wastewater from Taggiasca cultivar treatment onto activated carbon at different temperatures

\begin{tabular}{|c|c|c|c|c|c|c|}
\hline \multirow{2}{*}{$\frac{\text { Temperature }}{{ }^{\circ} \mathrm{C}}$} & \multicolumn{3}{|c|}{ Langmuir } & \multicolumn{3}{|c|}{ Freundlich } \\
\hline & $\frac{q_{\mathrm{m}}}{\mathrm{mg} / \mathrm{g}}$ & $\frac{K_{\mathrm{L}}}{\mathrm{mL} / \mathrm{mg}}$ & $\mathrm{R}^{2}$ & $\frac{K_{\mathrm{F}}}{(\mathrm{mg} / \mathrm{g})(\mathrm{mg} / \mathrm{mL})^{\mathrm{n}}}$ & $n$ & $\mathrm{R}^{2}$ \\
\hline 10 & 126.6 & 2.5 & 0.9401 & 79.6 & 2.3 & 0.7667 \\
\hline 25 & 156.2 & 1.6 & 0.9709 & 92.0 & 1.9 & 0.9511 \\
\hline 40 & 151.5 & 1.7 & 0.9194 & 89.4 & 2.2 & 0.9310 \\
\hline
\end{tabular}

$\mathrm{CAE}=$ caffeic acid equivalents, $\mathrm{AC}=$ activated carbon 
Table 3. Second-order kinetic parameters estimated for the sorption of phenolic compounds (expressed as mg of CAE per g of AC) from olive mill wastewater from Taggiasca cultivar treatment onto activated carbon at different temperatures

\begin{tabular}{|c|c|c|c|c|c|c|c|c|c|}
\hline \multirow[b]{3}{*}{$\frac{\gamma(\mathrm{AC})}{\mathrm{g} / 100 \mathrm{~mL}}$} & \multicolumn{9}{|c|}{$\frac{\text { Temperature }}{{ }^{\circ} \mathrm{C}}$} \\
\hline & \multicolumn{3}{|c|}{10} & \multicolumn{3}{|c|}{25} & \multicolumn{3}{|c|}{40} \\
\hline & $\frac{q_{\mathrm{e}}(\text { theoretical })}{\mathrm{mg} / \mathrm{g}}$ & $\frac{K_{2}}{\mathrm{~g} /(\mathrm{mg} \cdot \mathrm{min})}$ & $\mathrm{R}^{2}$ & $\frac{q_{\mathrm{e}}(\text { theoretical })}{\mathrm{mg} / \mathrm{g}}$ & $\frac{K_{2}}{g /(m g \cdot \min )}$ & $\mathrm{R}^{2}$ & $\frac{q_{\mathrm{e}}(\text { theoretical })}{\mathrm{mg} / \mathrm{g}}$ & $\frac{K_{2}}{\mathrm{~g} /(\mathrm{mg} \cdot \min )}$ & $\mathrm{R}^{2}$ \\
\hline 1.0 & 107.5 & 0.0010 & 0.9953 & 117.6 & 0.0025 & 0.9980 & 103.1 & 0.0010 & 0.9204 \\
\hline 2.0 & 101.0 & 0.0099 & 0.9576 & 90.9 & 0.0014 & 0.9393 & 88.5 & 0.0021 & 0.9925 \\
\hline 4.0 & 55.2 & 0.0083 & 0.9951 & 60.9 & 0.0073 & 0.9965 & 64.1 & 0.0023 & 0.9890 \\
\hline 6.0 & 43.7 & 0.0133 & 0.9998 & 45.2 & 0.0130 & 0.9989 & 46.3 & 0.0154 & 0.9991 \\
\hline 8.0 & 35.2 & 1.6131 & 0.9998 & 35.3 & 0.1213 & 0.9999 & 36.2 & 0.0290 & 0.9980 \\
\hline
\end{tabular}

$\mathrm{CAE}=$ caffeic acid equivalents, $\mathrm{AC}=$ activated carbon

anisms of sorption. The rate constants, the experimental and calculated equilibrium sorption capacities and the linear regression coefficients were obtained at all tested temperatures, and only the satisfactory results of the second-order model are summarized in Table 3. The correlation coefficients obtained by the Lagergren model were found to be less than 0.8750 , while those of the second-order model were higher than 0.9204 at all temperatures. These results, which are in agreement with those previously reported for the sorption of phenolics by activated carbon derived from agricultural waste material (16), demonstrate that only the latter model is able to satisfactorily describe the kinetic behaviour of the sorption of polyphenols by AC. Table 3 shows that the values of rate constant, $k_{2}$, increased from 0.0010 to 1.6131 at $10^{\circ} \mathrm{C}$, from 0.0025 to 0.1213 at $25^{\circ} \mathrm{C}$ and 0.0010 to 0.0290 at $40{ }^{\circ} \mathrm{C}$ with the increase of $\mathrm{AC}$ concentration from 1 to $8 \mathrm{~g}$ per $100 \mathrm{~mL}$.

The theoretical values of $q_{\mathrm{e}}\left(q_{\mathrm{e}}\right.$ (theoretical) $)$ were calculated using the second-order equation and it was observed that these values are in satisfactory agreement $\left(\mathrm{R}^{2}=0.9263\right)$ with the experimental $q_{\mathrm{e}}\left(q_{\mathrm{e}}(\right.$ experimental $\left.)\right)$ values at different temperatures and $\mathrm{AC}$ concentrations (Fig. 4). These observations suggest that the studied sorption systems follow the second-order kinetic model. Similar observation was reported in the literature for different adsorption processes $(16,28,43,44)$.

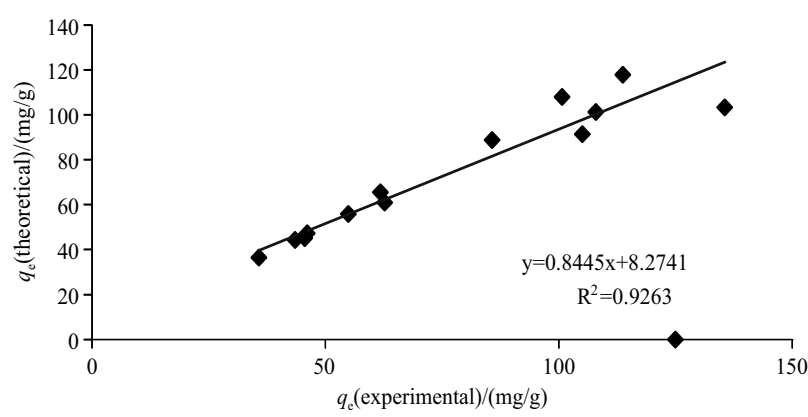

Fig. 4. Correlation between sorption capacities at equilibrium, expressed in mg of CAE per g of AC, calculated by second-order-rate model ( $q_{\mathrm{e}}$ (theoretical)) and those obtained by experiments $\left(q_{\mathrm{e}}(\right.$ experimental $\left.)\right)$. CAE $=$ caffeic acid equivalents, $\mathrm{AC}=$ activated carbon

\section{Conclusions}

Batch sorption tests were performed using different concentrations of activated carbon $(1,2,4,6$ and $8 \mathrm{~g}$ per $100 \mathrm{~mL})$ and temperature $\left(10,25\right.$ and $\left.45^{\circ} \mathrm{C}\right)$ for the removal of phenolic compounds from olive mill wastewater. Under optimum conditions (8 $\mathrm{g}$ of activated carbon per $100 \mathrm{~mL}$ ), the maximum sorption capacity of activated carbon was $35.8 \mathrm{mg} / \mathrm{g}$ at $10{ }^{\circ} \mathrm{C}, 35.4 \mathrm{mg} / \mathrm{g}$ at $25^{\circ} \mathrm{C}$ and 36.1 $\mathrm{mg} / \mathrm{g}$ at $40{ }^{\circ} \mathrm{C}$. The equilibrium data of total polyphenol sorption were fitted satisfactorily by the Langmuir isotherm at three different temperatures. The pseudo-second-order model $\left(\mathrm{R}^{2}>0.9204\right)$ explained better the adsorption kinetics as compared to the pseudo-first-order model $\left(\mathrm{R}^{2}<0.8750\right)$. The results of this study suggest that activated carbon can be used efficiently as an adsorbent for the removal of phenolic compounds from olive oil industry effluent. Pretreated wastewater has a potential as a clean substrate for the bioethanol production with the additional benefit of its use regarding the environmental and economical aspects. In addition, the adsorbed phenolic compounds can be recovered and after purification used in food, cosmetic and pharmaceutical industries.

\section{References}

1. Mulinacci N, Romani A, Galardi C, Pinelli P, Giaccherini C, Vincieri FF. Polyphenolic content in olive oil waste waters and related olive samples. J Agr Food Chem. 2001;49:3509-14. http://dx.doi.org/10.1021/jf000972q

2. Roig A, Cayuela ML, Sánchez-Monedero MA. An overview on olive mill wastes and their valorisation methods. Waste Manage. 2006;26:960-9. http://dx.doi.org/10.1016/j.wasman.2005.07.024

3. Zafra A, Juárez MJB, Blanc R, Navalón A, González J, Vílchez JL. Determination of polyphenolic compounds in wastewater olive oil by gas chromatography-mass spectrometry. Talanta. 2006;70:213-8. http://dx.doi.org/10.1016/j.talanta.2005.12.038

4. Galiatsatou P, Metaxas M, Arapoglou D, Kasselouri-Rigopoulou V. Treatment of olive mill wastewater with activated carbons from agricultural by-products. Waste Manage. 2002;22: 803-12.

http://dx.doi.org/10.1016/S0956-053X(02)00055-7 
5. Tuck KL, Hayball PJ. Major phenolic compounds in olive oil: metabolism and health effects. J Nutr Biochem. 2002;13:636-44. http://dx.doi.org/10.1016/S0955-2863(02)00229-2

6. Aliakbarian B, Dehghani F, Perego P. The effect of citric acid on the phenolic contents of olive oil. Food Chem. 2009;116: $617-23$. http://dx.doi.org/10.1016/j.foodchem.2009.02.077

7. Aliakbarian B, Palmieri D, Casazza AA, Palombo D, Perego P. Antioxidant activity and biological evaluation of olive pomace extract. Nat Prod Res. 2012;26:2280-90. http://dx.doi.org/10.1080/14786419.2012.660692

8. Casazza AA, Aliakbarian B, Perego P. Recovery of phenolic compounds from grape seeds: effect of extraction time and solid-liquid ratio. Nat Prod Res. 2011;25:1751-61. http://dx.doi.org/10.1080/14786419.2010.524889

9. Palmieri D, Aliakbarian B, Casazza AA, Ferrari N, Spinella $G$, Pane B, et al. Effects of polyphenol extract from olive pomace on anoxia-induced endothelial dysfunction. Microvasc Res. 2012;83:281-9. http://dx.doi.org/10.1016/j.mvr.2012.02.010

10. Ohno T, Inoue M, Ogihara Y, Saracoglu I. Antimetastatic activity of acteoside, a phenylethanoid glycoside. Biol Pharm Bull. 2002;25:666-8.

http://dx.doi.org/10.1248/bpb.25.666

11. Owen RW, Haubner R, Mier W, Giacosa A, Hul WE, Spiegelhalder $\mathrm{B}$, et al. Isolation, structure elucidation and antioxidant potential of the major phenolic and flavonoids compounds in brined olive drupes. Food Chem Toxicol. 2003;41: 703-17. http://dx.doi.org/10.1016/S0278-6915(03)00011-5

12. Khan AR, Al-Bahri TA, Al-Haddad A. Adsorption of phenol based organic pollutants on activated carbon from multicomponent dilute aqueous solutions. Water Res. 1997;31: 2102-12.

http://dx.doi.org/10.1016/s0043-1354(97)00043-2

13. Rengaraj S, Moon SH, Sivabala R, Arabindoo B, Murugesan V. Agricultural solid waste for the removal of organics: adsorption of phenol from water and wastewater by palm seed coat activated carbon. Waste Manage. 2002;22:543-8. http://dx.doi.org/10.1016/S0956-053X(01)00016-2

14. Özkaya B. Adsorption and desorption of phenol on activated carbon and a comparison of isotherm models. J Hazard Mater. 2006;129:158-63.

http://dx.doi.org/10.1016/j.jhazmat.2005.08.025

15. Walker PL. Production of activated carbons: use of $\mathrm{CO}_{2}$ versus $\mathrm{H}_{2} \mathrm{O}$ as activating agents. Carbon. 1996;34:1297. http://dx.doi.org/ 10.1016/0008-6223(96)82800-4

16. Singh KP, Malik A, Sinha S, Ojha P. Liquid-phase adsorption of phenols using activated carbons derived from agricultural waste material. J Hazard Mater. 2008;150:626-41. http://dx.doi.org/10.1016/j.jhazmat.2007.05.017

17. Qadeer R, Rehan AH. A study of the adsorption of phenol by activated carbon from aqueous solutions. Turk J Chem. 2002; 26:357-61.

18. Suen SY. A comparison of isotherm and kinetic models for binarysolute adsorption to affinity membranes. J Chem Technol Biotechnol. 1996;65:249-57.

http://dx.doi.org/10.1002/(SICI)1097-4660(199603)65:3<249: :AID-JCTB411>3.0.CO;2-M

19. Rege SU, Yang RT, Cain CA. Desorption by ultrasound: phenol on activated carbon and polymeric resin. Separations. 1998;44:1519-28. http://dx.doi.org/10.1002/aic.690440706

20. Ena A, Pintucci C, Carlozzi P. The recovery of polyphenols from olive mill waste using two adsorbing vegetable matrices. J Biotech. 2012;157:573-7. http://dx.doi.org/10.1016/j.jbiotec.2011.06.027
21. Grantt TM, King CJ. Mechanism of irreversible adsorption of phenolic compounds by activated carbons. Ind Eng Chem Res. 1990;29:264-71.

http://dx.doi.org/10.1021/ie00098a017

22. Knechtel RJ. A more economical method for the determination of chemical oxygen demand. Water Pollut Control. 1978; 116:25-9.

23. Garrote G, Dominguez H, Parajo JC. Kinetic modeling of corncob autohydrolysis. Process Biochem. 2001;36:571-8. http://dx.doi.org/10.1016/S0032-9592(00)00253-3

24. Swain T, Hillis WE. The phenolic constituents of Prunus domestica. The quantitative analysis of phenolic constituents. J Sci Food Agr. 1959;10:63-8. http://dx.doi.org/10.1002/jsfa.2740100110

25. Aliakbarian B, Casazza AA, Perego P. Valorization of olive oil solid waste using high pressure-high temperature reactor. Food Chem. 2011;128:704-10.

http://dx.doi.org/10.1016/j.foodchem.2011.03.092

26. Gutfinger T. Polyphenols in olive oil. J Am Oil Chem Soc. 1981;58:966-8. http://dx.doi.org/10.1007/BF02659771

27. Lagergren S. About theory of so-called adsorption of soluble substances. Kungliga Svenska Vetenskaps-akademiens handlingar. 1898;24:1-39.

28. Ho YS, McKay G. Pseudo-second order model for sorption processes. Process Biochem. 1999;34:451-65. http://dx.doi.org/10.1016/S0032-9592(98)00112-5

29. Langmuir I. The adsorption of gases on plane surfaces of glass, mica and platinum. J Am Oil Chem Soc. 1918;40:1361-403. http://dx.doi.org/10.1021/ja02242a004

30. Freundlich H. Adsorption in solution. Z Phys Chem. 1906;57:385-470 (in German).

31. Mohan D, Singh KP. Single-and multi-component adsorption of cadmium and zinc using activated carbon derived from bagasse - an agricultural waste. Water Res. 2002;36:2304-18. http://dx.doi.org/10.1016/S0043-1354(01)00447-X

32. Singh KP, Mohan D, Sinha S, Tandon GS, Ghosh D. Colour removal from wastewater using low cost activated carbon derived from agricultural waste material. Ind Eng Chem Res. 2003;42:1965-76. http://dx.doi.org/10.1021/ie020800d

33. László K, Tombácz E, Kerepesi P. Surface chemistry of nanoporous carbon and the effect of $\mathrm{pH}$ on adsorption from aqueous phenol and 2,3,4-trichlorophenol solutions. Colloid Surf A: Phys Eng Asp. 2004;13:230-8.

http://dx.doi.org/10.1016/j.colsurfa.2003.09.009

34. Mohanty K, Das D, Biswas MN. Treatment of phenolic wastewater in a novel multi-stage external loop airlift reactor using activated carbon. Sep Pur Technol. 2008;58:311-9. http://dx.doi.org/10.1016/j.seppur.2007.05.005

35. Zogorski JS, Faust SD. Equilibria of adsorption of phenols by granular activated carbon. In: Rubin AJ, editor. Chemistry of wastewater technology. Ann Arbor, MI, USA: Ann Arbor Science Publishers; 1978 . Chapter 9.

36. Asyhar R, Wichmann H, Bahadir M, Cammenga HK. Equilibrium adsorption studies of activated coke towards phenol and 4-nitrophenol. Fresenius Environ Bull. 2002;11:270.

37. Thawornchaisit U, Pakulanon K. Application of dried sewage sludge as phenol biosorbent. Biores Technol. 2007;98: $140-4$. http://dx.doi.org/10.1016/j.biortech.2005.11.004

38. Akgerman A, Zardkoohi M. Adsorption of phenolic compounds on fly ash. J Chem Eng Data. 1996;41:185-7. http://dx.doi.org/10.1021/je9502253

39. Galiatsatou P, Metaxas M, Arapoglou D, Kasselouri-Rigopoulou V. Treatment of olive mill waste water with activat- 
ed carbons from agricultural by-products. Waste Manage. 2002;22:803-12.

http://dx.doi.org/10.1016/S0956-053X(02)00055-7

40. Garcia-Araya JF, Beltran FJ, Alvarez P, Masa FJ. Activated carbon adsorption of some phenolic compounds present in agro-industrial wastewater. Adsorption. 2003;9:7-115. http://dx.doi.org/10.1023\%2FA\%3A1024228708675

41. Mohan D, Singh KP, Sinha S, Ghosh D. Removal of pyridine derivatives from aqueous solution using low-cost activated carbons derived from agricultural waste material. Carbon. 2005;43:1680-93.

http://dx.doi.org/10.1016/j.carbon.2004.04.026

42. Elaigwu SE, Usman LA, Awolola GV, Adebayo GB, Ajayi RMK. Adsorption of $\mathrm{Pb}(\mathrm{II})$ from aqueous solution by acti- vated carbon prepared from cow dung. Adv Nat Appl Sci. 2009;3:442-6.

http://dx.doi.org/10.3923/erj.2010.257.260

43. Kula I, Uğurlu M, Karaoğlu H, Çelik A. Adsorption of Cd(II) ions from aqueous solutions using activated carbon prepared from olive stone by $\mathrm{ZnCl}_{2}$ activation. Biores Technol. 2008;99:492-501.

http://dx.doi.org/10.1016/j.biortech.2007.01.015

44. Ben Hamissa AM, Lodi A, Seffen M, Finocchio E, Botter R, Converti A. Sorption of $\mathrm{Cd}(\mathrm{II})$ and $\mathrm{Pb}$ (II) from aqueous solutions onto Agave americana (L.) fibers. Chem Eng J. 2010; 159:67-74.

http://dx.doi.org/10.1016/j.cej.2010.02.036 